Volume and Issues Obtainable at Center for Sustainability Research and Consultancy
Journal of Business and Social Review in Emerging Economies
ISSN: 2519-089X \& (E): 2519-0326
Volume 7: Issue 2 June 2021
CSRட
Journal homepage: www.publishing.globalcsrc.org/jbsee

\title{
The Role of Higher Education as a Catalyst of Peace building in Conflict Affected Regions. The Case Study of Khyber Pakhtunkhaw after FATA Amalgamation
}

\author{
*Shabnam Shahab, PhD Scholar. The Department of Education BZU. Multan, Pakistan \\ Samee Ullah, The Department of Education BZU. Multan, Pakistan
}

*Corresponding author's email address: shahabshabnam786@gmail.com

\begin{tabular}{l} 
ARTICLE DETAILS \\
\hline History \\
Revised format: May 2021 \\
Available Online: Jun 2021
\end{tabular}

Keywords

Higher Education,

Peace building,

Educational Policies,

Barriers to Education,

FATA

JEL Classification

I23,129

\begin{abstract}
Purpose: Education is a corner stone for the social, economic, cultural and political development of any society. This research articulates the impact of Higher Education in the process of peacebuilding and violence free coexistence of post 9/11 context in Khyber Pakhtunkhwa (KPK) prior and after Federally Administered Tribal Area (FATA) amalgamation. The study critically reviews the educational structure, policies, emphasis, application of educational goals, achievements from rural to Higher education and protecting measures enabling the youth to get easy access to education. Since the creation of Pakistan emphasis laid down on the free and compulsory education for all but failed to address the nascent challenges surfaced in the form of violent extremism, sectarianism, intolerance, and lingual discrepancies. Although the literacy rate has been increased with the passage of time but the quality of education and practical application remains under darkness. The study has analyzed the role of higher education for community development, peace building in post conflicted areas such as Bosnia, Rwanda, Sudan, and Spain with the adoption of global approaches of stabilization, state-building, and civic training. But does this happen in Khyber Pakhtunkhwa? It has been established through empirical analyses that the framework of higher education has lain dormant and beyond the limits of easy access for the man in the street. The higher education role has been ignored in peace building and reconstruction era. This research in its findings proposes that the structure and curriculum of higher education be revisited and expanded promptly in Khyber Pakhtunkhwa (KPK) particularly within the newly merged areas for the restoration of social justice, cultural diversity, educational growth, state-building and peacebuilding community.
\end{abstract}

(C) 2021 The authors, under a Creative Commons AttributionNonCommercial- 4.0

- Recommended citation: Shahab, S., \& Ullah, S. (2021). The Role of Higher Education as a Catalyst of Peacebuilding in Conflict Affected Regions: The Case Study of Khyber Pakhtunkhwa after FATA Amalgamation. Journal of Business and Social Review in Emerging Economies, 7 (2), 279-289

\section{Introduction}

Pakistan has been given the title as "Land of Pure people" after its birth in 1947 as a revolutionary 
struggle against the British departure from the Sub-Continent. Historically, the North West region of Pakistan was subject to colonial administrative and governance rules which remain in force for many decades. The formerly FATA region for very long time remain the center of violent armed conflicts and wars due to which the state structure was completely destroyed. Although educational policies were initiated at the National level soon after the emergence of Pakistan but its practical application and proper educational growth in that region (FATA) seems to be a house of cards due to its complex tribal culture. The youth of this region including boys and particularly girls were forcefully deprived from the basic right of education over the decades. Pakistan grows gradually but to establish the peace and sustainable educational development remains in a state of fix. The history of violence-based incidents particularly in Khyber Pakhtunkhwa (KPK) and generally in Pakistan can be traced back after the communist invasion in 1979 and the War of resistance against that invasion in Afghanistan until 1992. In the era of state disintegration in Afghanistan more than 7 million Afghan refugees had shifted in the province of Khyber Pakhtunkhwa, Pakistan. It was a massive challenge to tackle these refugees including few groups of militants escaped from Afghanistan as a result of American invasion in 2002. The matter was not over yet surprisingly the incident of 9/11 took place which has further worsen the already pregnant situation in both Pakistan and Afghanistan. Moreover, the 9/11 event outbreaks the bloody war again in Afghanistan also with the beginning of insurgencies in Pakistan. The war of resistance and civil war altogether causes the unnatural death of more than 2 million people and approximately 5 million people were permanently disabled but the UN allies seems unsuccessful to restore peace and stability (Strand et al., 2017). The paper argues that present educational structure, curriculum, policies, and educational institutions have played their role to curb these violent attacks and does the higher education has any significant effects in newly merged areas and what measures has been taken now to maintain law and order situation by providing the access to higher education to the inhabitants of that localities suffered due to armed conflicts. The education institutions remain prime targets in armed conflicts in order to deprive the learners to pursue their higher education (Pherali \& Lewis, (2019). The present stage of unseen crises depicts pessimism but there is another world in which things are curable (Kajevska, 2020). Over the past 2 decades the limited literature has surfaced on the role of higher education in conflict affected areas. It has been comparatively analyzed with the post war reforms in Sudan, Rwanda, Kosovo, Iraq and Afghanistan. Analyses shed light on these studies that almost in all educational reforms the focus was on the national higher education programs for the reconstruction and rehabilitation of conflict affected areas (Milton \& Barakat, 2016). The research addresses that after the amalgamation of Federally Administered Tribal Area (FATA) with the Khyber Pakhtunkhwa how these conflicts affected areas can be reconstructed or rebuild through higher education. The research has focused on the universal mechanism of peacebuilding education in post conflict areas keeping in view the three approaches namely, Stability, Restructuring and peacebuilding through higher education.

The Directorate of Education situated in the former FATA Secretariat, developed a five-year comprehensive Education Sector Plan a planning document that was based on the 2009 National Education Policy (Naveed, 2018). The proposed educational plan sets forth the key barriers to education. After its amalgamation with Khyber Pakhtunkhwa new phase of reconstruction has taken place but the focus on higher education lain dormant. The primary, secondary and higher secondary educational institutions are also attacked and destroyed. Education has considered as corner stone for development of society and peacebuilding process but sadly it was not the priority of the policy makers to achieve its ultimate goals. The public sector universities in Khyber Pakhtunkhwa can play a role as catalyst to reform and rebuild the harmonious environment and led the society towards stabilization. The 40 year period of unrest in Afghanistan has left worsen effects on Pakistan's social, economic, and political culture. The educational policies in Pakistan had not addressed the need of the changing dimensions globally. The gross enrolment ration in public sector educational institutions is less than the proposed ratio in policy making decisions. The madrasa education could be taken into the government control and mutually agreed curriculum of peacebuilding, character-building, and state-building be expanded at all levels of education for violence free coexistence. The consistent approach is needed to formulate the smooth running of educational process, analyses of the data proved that there is major difference between the 
percentage of primary and secondary schools in rural and urban conflicted areas also as the level of education goes upward the chances to receive the higher education have reduced. The approach could also be implemented in Afghanistan also for the reformation of the society through education among other social development tools. This modal was used in Australia and Spain for the acquisition of civic and peaceful competence in schools to shape the individuals and community at large (Cabedo-Mas et al., 2017). Critical approach to education about the interpretation of religious beliefs can assist the young generation to mitigate the extremist and violent based ideology (Halafoff et al., 2019). The existing literature on peacebuilding with the context of post conflicted phase such as Sudan (Sørbø, 2010). Rwanda (Beswick, 2011) and Bosnia (Gromes, 2010) underpin numerous instruments to peacebuilding including educational, social, political and intercultural development. Intercultural and global approaches concerning peacebuilding and higher education lacked its enforcement and application (Deardorff, \& Arasaratnam, 2017). The article consists of three phases in phase one, it will address the conceptual framework and relationship of higher education with peacebuilding process. Phase two begins with the critical role of higher education as a catalyst of peacebuilding in conflict affected regions and phase three presents its core findings and empirical analyses relaying on the data of higher education institutions in Khyber Pakhtunkhwa before and after FATA amalgamation postulating three universal themes of Stabilization, State-Building, and Peacebuilding.

\section{A vulnerable and neglected sector}

The educational institutions in Khyber Pakhtunkhwa remain under consecutive terrorist attacks after 9/11. Two major conditions i-e physical destruction and permanent threat of assault to education sector endangered its existence in war regions. The state educational structure was also vulnerable and these insurgencies added fuel to fire. The higher education sector had been grossly neglected by the stakeholders. The concept to target higher educational institutions by armed groups is not new rather it is a planned war strategy as in the case of Iraq it was reported that $84 \%$ of higher education institutions were burned, looted, or destroyed during the post-invasion chaos (Reddy, 2005) Sectarian, lingual and armed attacks can trigger the forceful displacement of both learners and academics and this was the motive behind hitting the educational institutions in KPK. For example, after decades of conflict, Afghanistan had lost an estimated 20,000 experts and academics (MoHE 2009; Tierney,2011). since the commencement of armed conflicts in FATA the stakeholder priority was to protect and secure the infrastructure along with inhabitants but after FATA's merger with KPK the rebuilding phase has taken place and the stakeholders could have to properly address this issue by establishing and promoting higher education as a key tool for peacebuilding and reformation. The former FATA has a rich but riotous history due to its distinguished geographical scenario, tribal based social governance system and conjunctive border with fragile Afghanistan. The region is home of approximate 5.5 million people 49.13 percent of whom are women population. First time in the history of the Sub-Continent that region (FATA) has brought up into main streamline and through 25th constitutional amendment on 31 May, 2018 it was officially merged with Khyber Pakhtunkhwa but to attain the desired educational goals, peace, social order and rehabilitation have to be determined yet. The former FATA was once considered,

"The worst place for women to live, where all their basic rights to life are crushed. The region remained in the hands of the funded revolutionaries who killed, tortured, coercively confined and assassinated the women. All educational activities were strictly banned by radical leaders and pushed the region into the stone age".

\section{Objectives:}

\section{Research questions/ hypothesis}

\section{Methodology}

Research process was the following: To evaluate the educational targets and achievements of the elementary and secondary education in former FATA.

1. Historical method of research was adopted. 
2. Journal and research project reports related to evaluation of educational targets and achievements were studies.

3. Education policies from the dawn of freedom 1947 to 2010 were studies.

4. five-year government plans were studies.

5. Reports and related literature was consulted to study the educational targets and achievements of the elementary and secondary education.

6. The provincial initiative of Educational sector plan (ESP) and its practical outcomes were critically analyzed.

7. Post conflict educational barriers and economic hindrances has taken into consideration for future educational reforms and rehabilitation.

\section{The relationship between higher education and peacebuilding; Conceptual analysis}

This research goes away from the traditional ideology of conflict and peacebuilding but in line with the work of Johan Galtung who describes peace as negative and positive. He further elaborates negative peace as primarily the absence of direct violence and positive peace as the combination of processes, mechanisms, stability of institutions, and conduct which ensures violence free, sustainable, peaceful social structure. The present study takes peacebuilding as the corner stone of development process including diverse ideologies, philosophies, tools, and methodology mitigating fierce conflict to transform sustainable state building relations. In this array of cognitive process higher education is one of them which is indivisible element of peacebuilding. Higher education is not a peripheral player but is a pivotal and central component of harmony and peace. In addition, higher education due to its intrinsic uniqueness can bolster the process of peacebuilding by taking away the social, cultural, economic and political inequalities. Thus, higher education has the unquestioned characteristics to lessen the violence and threat of conflict. For example, the Hindu nationalists in India and the ruling elites in Pakistan controlled the process and development of education in order to remain dominant and influential over the governance system (Lall, 2018). The pages of history reveals that there is indiscrete nexus between higher education and extremism, violence, and intolerance. Only higher education can remedy the roots of conflicts because academics and dedicated learners are often head the ferocious movements (Hayman, 2007). Very recently the Higher education has been observed as a major component to development of peacebuilding process that allows human, cultural, linguistic, socio political and educational progress through,

"The formation of human capital (primarily through teaching); the building of knowledge bases (primarily through research and knowledge development); the dissemination and use of knowledge (primarily through interactions with knowledge users); and the maintenance of knowledge (inter-generational storage and transmission of knowledge)" (Santiago et al., 2018).

\section{The review of educational institutional planning in Khyber Pakhtunkhwa}

Number of all level schools in KPK in 2017-18.

Table 1. Source. Department of elementary and secondary education, (ESED) KPK.

\begin{tabular}{ccccc}
\hline All level schools & Female schools & Male schools & Total & Percentage \\
\hline Mosque & & 877 & 877 & 3.06 \\
\hline Primary & 8698 & 13036 & 21,734 & 76.04 \\
\hline Middle & 1284 & 1553 & 2837 & 9.92 \\
\hline Secondary & 905 & 1523 & 2428 & 8.49 \\
\hline Higher secondary & 260 & 445 & 705 & 2.46 \\
\hline Total & 11,147 & 17434 & 28,581 & $100 \%$ \\
\hline
\end{tabular}

The data in table 1 deals with the statistics of all level school institutions including the religious Madrassa's which takes students for early education. The analyses of the data proved that almost 76 
percent schools deal with the primary education (early education) and about 18 percent school institutions meet the requirements up to secondary level. Only about $2.46 \%$ educational institutions are providing higher secondary education which is evident that the stakeholders have not addressed the enrolment ratio of students at the higher secondary level due to which the number of higher secondary institutions have not increased. This is the area which needs serious attention of concerned authorities to be promoted as a necessary component of peacebuilding process.

Number of students in all types of schools in 2017-18

Table 2. Source. Department of elementary and secondary education, (ESED) KPK.

\begin{tabular}{lllll}
\hline \multicolumn{1}{c}{ All level schools } & \multicolumn{1}{c}{ Male } & \multicolumn{1}{c}{ Female } & \multicolumn{1}{c}{ Total } & \multicolumn{1}{c}{ Percentage } \\
\hline Public sector & 2468791 & 1914997 & 4383788 & 65.41 \\
\hline Private sector & 1428867 & 642653 & 2071520 & 30.91 \\
\hline $\begin{array}{l}\text { Religious } \\
\text { institutions }\end{array}$ & 205576 & 40787 & 246363 & 3.67 \\
\hline Total & 4103234 & 2598437 & 6701671 & $100 \%$ \\
\hline
\end{tabular}

Table 2 addresses the ratio of students in all sectors of educational institutions according to which 65 percent students were enrolled in public sector (government sector) institutions and about 31 percent were enrolled in private sector (non-government) and 3.67 percent got the attention of religious Maktabas. Table one shows that 76 percent students have tried to get their early education but gradually they were taken away from the educational institutions and resultantly only 3 percent students reached at higher secondary level as per their availability.

Number of all Government schools lacking basic requirements in KPK in 2017-18

Table 3. Source. Department of elementary and secondary education, (ESED) KPK.

\begin{tabular}{|c|c|c|c|c|c|c|c|c|c|c|c|c|}
\hline \multirow{2}{*}{$\begin{array}{l}\text { Institutional } \\
\text { level }\end{array}$} & \multicolumn{3}{|c|}{ Drinking water } & \multicolumn{3}{|c|}{ Electricity } & \multicolumn{3}{|c|}{ Boundary wall } & \multicolumn{3}{|c|}{ Toilets } \\
\hline & Boys & girls & total & Boys & girls & total & Boys & girls & total & Boys & girls & total \\
\hline Primary & 2477 & 1298 & 3775 & 5704 & 2676 & 8380 & 2111 & 560 & 2671 & 2240 & 896 & 3136 \\
\hline Middle & 407 & 194 & 601 & 409 & 291 & 700 & 108 & 56 & 164 & 96 & 45 & 3136 \\
\hline High & 126 & 48 & 174 & 144 & 69 & 213 & 96 & 26 & 122 & 56 & 37 & 93 \\
\hline $\begin{array}{l}\text { Higher } \\
\text { secondary }\end{array}$ & 82 & 74 & 156 & 37 & 29 & 66 & 33 & 26 & 59 & 29 & 17 & 46 \\
\hline Grand total & 3092 & 1614 & 4706 & 6294 & 3065 & 9359 & 2348 & 668 & 3016 & 2421 & 995 & 3416 \\
\hline
\end{tabular}

Table 3 argues about the lack of basic necessities in educational institutions. As per the data of table one there were 28.581 schools from primary level to higher secondary level in the KPK province until 201718. The data in table three illustrates that out of total (28581) schools the 20497 schools $(71.71 \%)$ out of $(100 \%)$ schools have lacked fundamental requirements. Among from the majority of these schools were remain the prime target for violent armed attacks but this may be the one out of several reasons for freezing the sustainable educational development.

\section{Educational structure in former FATA before amalgamation}

According to Annual education census data 2017 there were only 5874 public sector educational institutions in former FATA out of which 5234 were functional and 1987 were providing education to girls. The majority of the schools belongs to the primary sector and higher education institutions were seriously neglected. The former FATA secretariat's initiative on Educational sector plan (ESP) had focused only the establishment of primary sector education and ignored the necessity to laid the foundation of colleges and universities. The political culture and influence in the seven former FATA agencies can-not be simply ignored as were highlighted in the ESP by concerned authorities that 
politicians are not in favor to establish the higher education institutions for girls. The local warlords are the owners of the land situated within the former FATA who only render few part of the land for primary schools and government seems paralyzed to acquire more land for better educational growth and development.

\section{The role of varsities in KPK for establishing Educational Growth}

As per the statistics of the Higher Education Commission of Pakistan (HEC) there are 21 public sector universities and 10 private sector universities in Khyber Pakhtunkhwa. Out of these 31 public and private sector universities 12 universities are situated at the provincial headquarter (Peshawar). It is proved that there was no university in the former FATA region for the higher education of youth to provide the "free and compulsory" education as envisioned in various educational policies and plans. Annual Education Census data revealed the fact that the enrolment ratio of girls at the secondary level institutions is lowest at the country level and this is what happening in universities also. Apart from the universities located at Peshawar the rest of public and private sector universities are beyond the easy access of newly merged region population.

\section{The role of higher education as a catalyst of peacebuilding in post conflict regions}

Peacebuilding is a very complex phenomena with the context of Pakistan and Afghanistan. The concept of War, invasion, and Civil War needs clarity from the unbiased academics before nurturing the peacebuilding and state-building. The Afghan nationals consider Soviet attack as invasion while the opponents take it as a War but some other academics define it the period of unrest and civil war in Afghanistan. Moreover, after 9/11 the approach within the Afghanistan was again divided the former state representatives consider the defensive measures against Afghanistan as American invasion like Soviet invasion while opponents perceive it a War against terrorism in which Pakistan was also an alley with the international community. The developed countries assessed the Afghanistan after 2003 as post conflict region but this was the beginning of the resistance movement in Afghanistan and the era of civil war in Khyber Pakhtunkhwa including formerly Fata. During the unrest period in Afghanistan the educational ideology was trapped between Communism and Islamic ideology in 1979 as first phase and between capitalism vs Islamic ideology in 2001 as second phase. In Afghanistan, Libya, and Sierra Leone during the conflicts the Higher education institutions were completely destroyed as a result of war and large population (including learners and academics) was displaced permanently.

\section{The case of higher education in Afghanistan}

The foundation of higher education in Afghanistan was laid down in 1932, however with the passage of time other higher education institutions like Nangarhar, Herat, Kandahar universities were established. The gradual process of social development and intellectual growth remain in force even during the period of agony which resultantly paved the way for the formation of teachers and student unions led by communist and Islamic political leaders who time to time questioned the legitimacy of the state. Although there were political discrepancies but the constant state of unrest pressed the necessity of peace through dialogic pedagogy. This remarkable development resulted from the higher education has had unquestioned implications as three dominant ideological and political groups I-E Pro Soviet, Pro Islamic, Pro Communist and Nationalist ideologies surfaced during this phase. So higher education had played palatial role irrespective of the circumstances. In Afghanistan after decades of unrest and rebellions the country had suffered the irreparable loss of 20.000 educationists and academics (MoHE and IIEP, 2004). Similarly, in 2003, the Asian Development Bank reported that the education system in Afghanistan has collapsed (Sarvi, 2003). Another study states that during the period of war majority of the academics and learners, staff and administrators were either killed or displaced and campuses were destroyed.

\section{The Rehabilitation Phase}

Undoubtedly the sector of higher education was vulnerable during conflicts in Afghanistan. Historically higher education in post conflicted areas expanded slowly and the enrolment of students significantly increased from less than 8,000 in 2001 to about 152,000 in 2012 (Gropello, 2011) and grew to 174,425 as 
of 2015 (USAID 2021). The number of higher education institutions have been rapidly increased in recent years and there are now 36 public sector universities and 131 private sector universities in Afghanistan (Datzberger, et al., 2015). The major move is done towards bringing the girls into main stream by providing the opportunities of basic and higher education deprived previously. Despite the educational barriers and lack of institutions women's education has gradually attained the lost glory and all this happen with due political will and international intervention. Education is now driving the social, cultural and economic development as part of peacebuilding process.

Unfortunately, the underline purpose of higher education has not achieved yet due to quest for attaining key designation within the higher education institutions, financial issues, inefficient governance structure, undermining its role, disciplinary challenges and several other factors render the sector towards instability (Collier, et al., 2008). One of the senior intellectual at Herat university expressed his concerns in the following ways,

"University sites are increasingly becoming home to politically active academics and students where some of them nurture extreme views on some issues e.g. democracy, Islam, women's rights, human rights and the West's intervention". (Johnson, 2013).

Another academic official at Kabul university states that the rapid increase of university students and academics in promoting the violent and ethical differences would trigger the higher education sector towards ultimate destruction. She further added,

"Students and academics across the universities, have played a leading role in organizing riots that turned ugly and violent, civil disobedience and civil unrests". (Cabedo-Mas et al., 2017)

One of the Vice Chancellor of private university at Kabul argues that,

"Many political and social parties have infiltrated universities and groomed lots of academics and students into their extremist views and agenda. This is an alarming threat to the stability of Afghanistan and must be addressed immediately". (Sahar \& Kaunert, 2021).

The major cause for this instability of higher education was observed that the curriculum was not updated regularly and the academic officials who occupied these educational offices during the period of unrest (1978-2001) were not highly trained and failed to adopt the approaches, dimensions, methodologies taking place globally including research and practical outcome. All other activities excluding scholar, cognitive and academic activities were carried out within the higher education campuses. Keeping in view these loopholes within the higher education sector it can be restructured by the positive use of eligible human capital, resources, institutional reforms, rational development, just and fair democratic process, civic training, abolishment of foreign intervention, equal distribution of resources etc. The official at the Ministry of Higher Education (MOHE) stated that,

"The progress we have achieved in the past 18 years is at risk as political stability and security worsen, which could lead the country to yet another round of chaos. One of the areas we should look to as a buffer is institution-building and $\mathrm{HE}$ is particularly important. Because $\mathrm{HE}$ is the foundation of good citizenship, politics, and economy. If a nation has a skilled and committed people, one day, it will find its way to prosperity. (Novelli \& Smith, 2011).

The enthusiastic efforts of the international family for the state-building, reclamation and social integrity in Afghanistan has not cemented due to four core reasons i-e incumbent public and private office holders throughout the country, pervasive level of corruption, flourishing drug economy and malpractices. The higher education has not considered a sole player in Afghanistan for the revival of fractured social fabrics and state-building but a marginal player. 
From 1978 to 2015 the State had lost the control of educational institutions resultantly the institutions and learners were dominated by the local warlords and recruit the students for the accomplishment of their funded and self- initiated political ideologies. Despite the fact the higher education is making progress in Afghanistan under the circumstances of fear and threat.

\section{Key Educational Restraints}

Educational Barriers In Newly Merged Region (FATA)

Some basic educational barriers have been observed in the newly merged region (FATA) of KPK as fundamental restraint for girls to pursue education namely,

1. The major was the parental mind set that education is not useful for women and is followed as cultural obstacle.

2. More than 60 percent inhabitants are living below the poverty line due to lack of employment opportunities, industries, government structure, institutions both public and private so how can they spend on education.

3. The existing primary and secondary schools are far away from the villages/localities and there is no governmental set up of transportation and security which endangers the movement of the girls. The geographical situation of the region is complex and the militants can easily hit their targets (girls) and escaped.

4. Out of total number of schools only 11 percent are dealing with the secondary and higher secondary education ( 7 percent of which grossly lacks basic facilities) and in the newly merged region the number of these institutions are insufficient to take all the primary graduates.

5. In Pakistan education has become a matter of employment (which originally was not the purpose of education) the parents in tribal areas confined their girls within the boundary of four walls as they perceive no employment gain after education.

6. The FATA's educational sector plan (ESP) was for the primary sector only and failed to provide the line of action and clear strategy for the establishment of higher education in the newly merged region.

7. The teachers and staff were not properly trained who had not delivered the real purpose of education and its importance in the lives of the human beings.

8. The curriculum was not updated and revised as per the changing needs and intellectual growth and left the already weak system on the disposal of those who had rigid thoughts and were not ready to accept the universal approaches and research methodologies.

9. During the armed attacks and military operations the majority of the people were displaced from their hometowns and provided temporary residence at other areas where no educational system for the young learners was maintained.

10. The tribal culture and governance system of social life set in motion by the British rulers in former FATA which remain in force for almost two centuries had deep cultural influence over the local citizens and contrary to the vision of the father of Nation about women's education.

11. The provincial and Federal governments had not invited the private sector to establish educational and community schools to tie hands with the governments to literate the more devoted learners and enable them to lead a prosperous life.

12. The qualified female staff in girl schools was not hired according to need and no female role model had been portrayed for the motivation of the girls education.

\section{The overview of national educational policies and application in former fata}

Since the partition of the Sub-continent in 1947 seven educational policies were announced in Pakistan with the traditional recommendations, suggestions, implementation measures and goals without conducting comprehensive review on each policy and its practical outcomes. In all the policies the theme 
was the same which has damaged the educational structure in Pakistan. It needs to be addressed at the time of Communist intrusion in Afghanistan in 1979 under the intellectual supervision of the foreign educated experts for further policy making, designed and updated curriculum to counter the repercussions of Afghan war on Pakistani society. The last policy (1998-2010) has determined slightly changed priorities particularly the inclusion of establishment and access to higher education institutions, skilled academics, enhancing the role of community organizations along with government sector and the elimination of social disparity. But like other educational policies it has also some loopholes which need to be addressed timely for concrete social development and state-building.

\section{Recommendations and finding a way forward}

1. The dedicated political stability and will is required to transform the sick educational structure irrespective of political gains and affiliations.

2. There should be two Educational Commission at national level one can monitor the educational growth from primary to higher secondary and second can look after the educational achievements at higher level.

3. The National Education Commission should be established in which the equal representation should be given to each province and their educational experts could review the outcomes of the previous policy and frame new policy in line with the culture, civilization, ideology of Pakistan keeping in view the global changes.

4. The private educational culture in Pakistan should be reduced and the capacity of the government sector could be focused and increased with strict administrative policies.

5. The educational policies can be made keeping in view the economic condition of the country because if this element has not into consideration than no plausible implementation would take place as currently going on at various educational levels.

6. Separate colleges for boys and girls and universities should be established promptly at each district head quarter of newly merged regions of KPK and skilled administrative, highly qualified, unbiased staff be recruited for the cognitive development of the learners for peacebuilding and state-building.

7. The number of higher secondary schools be accelerated in accordance with the percentage of the students graduated from the primary sector and secured their enrolment in higher education institutions.

8. Free transport be provided to the students of the newly merged region of KPK in order to develop their educational attitude and hurdle free access to educational institutions.

9. The budget should be allocated subject to performance and achievements of settled educational goals and the promotion of the staff should also be subject to special educational audit of the institutions.

10. The curriculum should be reframed considering the cultural diversity, focusing the role of education towards peacebuilding and state-building process, enabling the students to live a responsible life and develop their political ideologies to protect the national interest and their affiliations remain with the integrity of the state rather to support the bifurcating ideologies propagating linguistic, Ethnic, or sectarian theme.

11. The political pressure in the educational institutions concerning transfer, promotion, and appointments should be abolished to make the institutional growth free from influence.

12. The new syllabi of peace building education and character growth of the learners be included at the intermediate, graduation, and higher educational level in order to diminish the influence of the violent culture of Afghanistan on KPK educational institutions.

13. The state shall provide the land and all relevant facilities to educational sector instead of throwing the matter for decision to the local feudal lords as was happened previously.

14. The special quota for foreign scholarships be fixed for the students of the former FATA to motivate them for higher learning.

15. To attract the attention towards education monthly based stipend (whatsoever the amount) should be provided initially to each student to meet their educational expenses independently 
be announced by the Provincial Government with due check and balance.

\section{Conclusion}

Since the inception of Pakistan the educational priorities were differed from the demand. The disruptive political system and discrepancy between civil and army approach over the institutional reforms and sustainable educational growth has fractured the fabric of educational sector. Seven educational policies, eight five year plans and many other educational strategies have been inked and promulgated but implementation hindrances remain dominant and progress stay stagnant. There was no concrete educational structure in FATA and policies were made to address the initial level of education while secondary and higher education were grossly neglected. The history in the conflict region has been changed now after former FATA amalgamation with Khyber Pakhtunkhwa and light of hope sparked after four decades of persistent butcherly unrest which deprived the young learners from their basic rights including education. Furthermore, if it was a political strategy to expand the provincial authority without addressing the core issues for which the FATA was merged it would be more exploitative if no groundbreaking development has taken place. It is the desperate need of time to restructure the inanimate institutions and take speedy developmental measures. Education can play the role as catalyst in the peacebuilding, stabilization and state-building process along with other tools of societal integrity and sustainable development. The former Afghan minister highlight the role of higher education in peacebuilding process in the following manner,

"In the current context of Afghanistan, HE is playground where the infrastructure of peace can be developed and sustained. Because HE gives you a powerful mechanism and tool through which you can build the preconditions of peacebuilding agendas. HE in addition to empowering individuals and train them into responsible citizens can bring opposing parties together. So, these parties then get peace education, forge friendly relationships, and connect academics across different establishments of peacebuilding as a discipline". (Millican, 2017)

\section{References}

Beswick, D. (2011). Aiding state building and sacrificing peace building? The Rwanda - UK relationship 1994-2011. Third World Quarterly, 32 (10), 1911-1930.

Cabedo-Mas, A., Nethsinghe, R., \& Forrest, D. (2017). The role of the arts in education for peacebuilding, diversity and intercultural understanding: A comparative study of educational policies in Australia and Spain. International Journal of education \& the Arts, 18(11).

Cabedo-Mas, A., Nethsinghe, R., \& Forrest, D. (2017). The role of the arts in education for peacebuilding, diversity and intercultural understanding: A comparative study of educational policies in Australia and Spain. International Journal of education \& the Arts, 18 (11).

Collier, P., Hoeffler, A., \& Söderbom, M. (2008). Post-conflict risks. Journal of Peace Research , 45 (4), 461-478.

Datzberger, S., McCully, A., \& Smith, A. (2015). Education and Peacebuilding in Uganda: The Role of Education in Peacebulding Country Report: Uganda. Datzberger, S., McCully, A., \& Smith, A. (2015). Education and Peacebuilding in Uganda: The Role of Education in Peacebulding Country Report: Uganda.

Deardorff, D. K., \& Arasaratnam, L. A. (2017). Intercultural competence in international higher education. Intercultural competence in higher education: International approaches, assessment and application, 294-302

Di Gropello, E. (2011). Putting higher education to work: Skills and research for growth in East Asia. World Bank Publications.

Gromes, T. (2010). Federalism as a means of peace-building: The case of Postwar Bosnia and Herzegovina. Nationalism and Ethnic Politics , 16 (3-4), 354-374.

Halafoff, A., Lam, K., \& Bouma, G. (2019). Worldviews education: Cosmopolitan peacebuilding and preventing violent extremism. Journal of Beliefs \& Values , 40 (3), 381-395.

Hayman, R. (2007). Are the MDGs enough? Donor perspectives and recipient visions of education and 
poverty reduction in Rwanda. International Journal of Educational Development, 27 (4), 371382.

Johnson, A. T. (2013). University agency in peacebuilding: Perspectives on conflict and development in Kenya. Prospects, 43(3), 329-345.

Kajevska, A. M. (2020). Universities and conflict: the role of higher education in peacebuilding and resistance: edited by Juliet Millican, London and New York: Routledge, 2018, 254 pp.,£ 84.00 (hardback),£ 31.99 (eBook), ISBN 978-1-138-09213-6.

Lall, M. (2008). Educate to hate: The use of education in the creation of antagonistic national identities in India and Pakistan. Compare, 38 (1), 103-119.

Millican, J. (Ed.). (2017). Universities and conflict: The role of higher education in peacebuilding and resistance . Routledge.

Milton, S., \& Barakat, S. (2016). Higher education as the catalyst of recovery in conflict-affected societies. Globalization, Societies and Education, 14 (3), 403-421.

Ministry of Higher Education (2009). National Higher Education Strategic Plan: 2010-2014. The Ministry of Higher Education, Government of Afghanistan. Kabul.

Ministry of Higher Education, and UNESCO-IIEP. 2004. "Strategic Action Plan for the Development of Higher Education in Afghanistan." Kabul, Afghanistan

Naveed, S. (2018). The Importance of Educating Girls in the Newly Merged Districts of Khyber Pakhtunkhwa, Pakistan. Echidna Global Scholars Program, Policy Paper. Center for Universal Education at The Brookings Institution .

Novelli, M., \& Smith, A. (2011). The role of education in peacebuilding: A synthesis report of findings from Lebanon, Nepal and Sierra Leone.

Pherali, T., \& Lewis, A. (2019). Developing global partnerships in higher education for peacebuilding: a strategy for pathways to impact. Higher Education , 78 (4), 729-744.

Reddy, J. (2005). 5 / 6ths of Iraq's Higher Learning Institutions Burnt, Looted, Wrecked; 48 Profs Slain; UNU Calls for World Help to Repair System. United Nations University.

Sahar, A., \& Kaunert, C. (2021). Higher education as a catalyst of peacebuilding in violence and conflictaffected contexts: the case of Afghanistan. Peacebuilding , 9 (1), 57-78.

Santiago, P., Tremblay, K., Basri, E., \& Arnal, E. (2008). Tertiary education for the knowledge society (Vol. 1). Paris: OECD.v

Sarvi, J. (2003). A new start for Afghanistan's education sector.

Sørbø, GM (2010). Local violence and international intervention in Sudan. Review of African Political Economy, 37 (124), 173-186.

Strand, A., Borchgrevink, KCA, \& Harpviken, KB (2017). Afghanistan: A Political Economy Analysis.

Tierney, WG (2011). The role of tertiary education in fixing failed states: Globalization and public goods. Journal of Peace Education , 8 (2), 127-142.

USAID, 'Education in Afghanistan', <https://www.usaid.gov/afghanistan/education. (accessed 12 January 2021). 